\title{
RONA PERILAKU (BEHAVIOR SETTING) DAN KEPUASAN PENGHUNI SEBAGAI DASAR PENYEMPURNAAN KRITERIA RANCANG BANGUN RUSUNAWA (Studi Kasus: Rumah Susun Sederhana Sewa di Malang )
}

\author{
Edi Subagijo* \\ Jurusan Arsitektur, Fakultas Teknik, Universitas Merdeka Malang \\ *edisubagijo@yahoo.co.id
}

\begin{abstract}
ABSTRAK
Perkembangan teknologi sangat pesat, berbagai bentuk arsitektur sangat beragam dan lebih inovatif. Disain arsitek lebih mencerminkan ke arah masa depan daripada ke masa silam. Konservasi arsitektur dianggap kurang mengakomodasi tuntunan jaman dan ekonomis. Namun masih ada faktor-faktor dari aspek manusia yang dilupakan. Seperti contoh rumah susun di negara lain yang sudah dihuni selama berpuluh-puluh tahun telah menimbulkan permasalahan. Kegagalan rumah susun di negara lain tidak disebabkan oleh faktor teknis, justru faktor non teknis, yaitu faktor manusia sebagai penghuni kurang mendapat perhatian seperti: Rumah susun 12 lantai Pruit lgoe di St. Louis tahun 1972 dan rumah susun Ronan Point di Inggris tahun 1968, telah dibongkar karena banyak permasalahan sosial. Manusia sebagai mahluk sosial tidak bisa hidup, jika tidak berdampingan dengan manusia lain untuk berinteraksi sosial. Gerakan sejuta rumah dan seribu tower yang dicanangkan oleh pemerintah Indonesia akan memicu pembangunan rusunawa di kota-kota besar. Kota Malang sebagai kota besar ke 2 di Jawa Timur, sudah membangun rusunawa sejumlah 2 blok, terdiri 3 lantai dan dihuni selama 10 tahun.

Penelitian deskriptif dengan menekankan aspek spesifik yaitu persepsi dan perilaku. Kepuasan penghuni dalam melakukan kegiatan bersama dapat diukur dengan persepsi penghuni melalui kuesioner, terutama kepuasan terhadap privacy, teritoriality, dan crowding, kemudian dianalisis dengan model skala Osgood dan Likert, kemudian hasilnya ditabulasikan. Sedangkan rona perilaku (behavior setting) melalui pengamatan di lapangan, dicari sebab akibat pola perilaku kebersamaan itu terjadi, kemudian dianalisis pengaruh elemen-elemen arsitektur apa yang mempengaruhinya. Selasar yang cukup luas, setiap unit rumah saling berhadapan, void di tengah untuk masuknya cahaya matahari dan setiap lantai bisa saling melihat, merupakan tempat yang paling sering untuk berinteraksi sosial. Selasar merupakan ruang multifungsi yang digunakan penghuni berinterksi sosial. Responden merasa cukup puas dalam melakukan kebersamaan di Ruang bersama (selasar, MCK umum, dan Dapur).
\end{abstract}

Kata Kunci : rona perilaku, behavior setting, privacy, teritoriality, dan crowding.

\section{PENDAHULUAN}

\section{Latar Belakang}

Pembangunan perumahan oleh pemerintah untuk memenuhi kebutuhan perumahan yang layak senantiasa dilakukan dengan berbagai cara. Salah satu langkah yang dilakukan oleh pemerintah adalah pembangunan rumah susun bersubsidi yang selama ini telah banyak memberikan sumbangsih bagi pemenuhan kebutuhan bagi masyarakat ekonomi lemah, terutama di kota-kota besar yang berpenduduk padat. 
Pembangunan rumah susun di kota-kota besar merupakan konsekuensi logis dalam mengantisipasi perkembangan kotanya, terutama di kawasan permukiman yang berfungsi sebagai pusat perekonomian. Di Kawasan perekonomian merupakan incaran warga kota untuk memenuhi kebutuhan hidupnya terutama bagi warga yang bergerak pada sektor informal. Pada gilirannya di daerah sektor ekonomi terjadi kepadatan yang tinggi, sehingga harga lahan semakin tinggi, kebutuhan lahan terus meningkat, akhirnya masyarakat berpenghasilan rendah tidak bisa menjangkaunya.

Rusunawa Kotobedah yang terletak di wilayah Kecamatan Kedung Kandang Kota Malang merupakan rusunawa pertama pada tahun 1998 baru dihuni. Berlantai 3, terdiri dari 2 blok, dalam 1 blok terdiri dari 54 unit rumah tinggal. Kebanyakan para penghuninya berasal dari kampung kumuh di pinggir sungai Berantas, pada saat di kampung masih guyub (akrab).

Manusia sebagai mahluk sosial tidak bisa hidup berdampingan dengan manusia lain untuk berinteraksi sosial dengan sesamanya. Untuk menciptakan kondisi penghuni rumah susun yang tidak individualitis perlu diciptakan suatu rona perilaku (behavior setting) untuk berinteraksi sosial, sehingga dapat meningkatkan kehidupan sosialnya dan dapat membentuk masyarakat yang komunal (guyub).

Perumusan masalahnya : Bagaimana kepuasan dan Rona Perilaku (Behavior setting) penghuni rusunawa dalam berinteraksi sosial ?
Tujuannya untuk mencari rona perilaku (behavior setting) dan mengukur tingkat kepuasan penghuni (privacy, teritoriality, crowding) dalam berinteraksi sosial di ruang bersama. Manfaat penelitian ini secara menyeluruh diharapkan dapat dipakai sebagai masukan untuk perbaikan panduan kriteria rancang bangun Rususnawa, karena pada dasarnya aspek manusia sebagai pemakai tidak bisa terlepas dari bagian perancangan.

\section{Interaksi Manusia dengan Lingkungan}

Perilaku manusia timbul akibat adanya interaksi antara manusia dengan lingkungannya (Kurt Lewin, 1951). Perilaku manusia ini adakalanya menye-suaikan diri terhadap lingkungannya, karena manusia mempunyai kemampuan besar untuk beradaptasi (Gump,1971). Di samping itu ada juga manusia merubah lingkungannya supaya sesuai dengan perilakunya (Michelson,1977), (Piaget,1953). Lingkungan yang sesuai dengan perilakunya merupakan rona (setting) pilihan terbaik.

Fasilitas umum sebagai sarana kegiatan bersama dan terjadi interaksi sosial, merupakan rona terbaik yang diminati dan dipilih penghuni untuk berinteraksi sosial. Interaksi Manusia dengan Lingkungan Manusia dan alam lingkungannya merupakan satu kesatuan yang tidak dapat dipisahkan, ke duanya merupakan suatu jalinan transactional interdependency atau terjadi saling ketergantungan satu sama lainnya. Artinya terjadi timbal balik manusia mempengaruhi lingkungannya dan lingkungan mempengaruhi manusia. Lingkungan yang dimaksud dapat berupa 
lingkungan fisik, baik yang alamiah maupun buatan dan lingkungan sosial budaya. (Rapoport,1976),

Menurut Altman (1980), bahwa proses hubungan manusia dengan lingkungannya terdapat ada lima unsur yang saling pengaruh mempengaruhi, seperti dijelaskan secara skematis pada gambar :

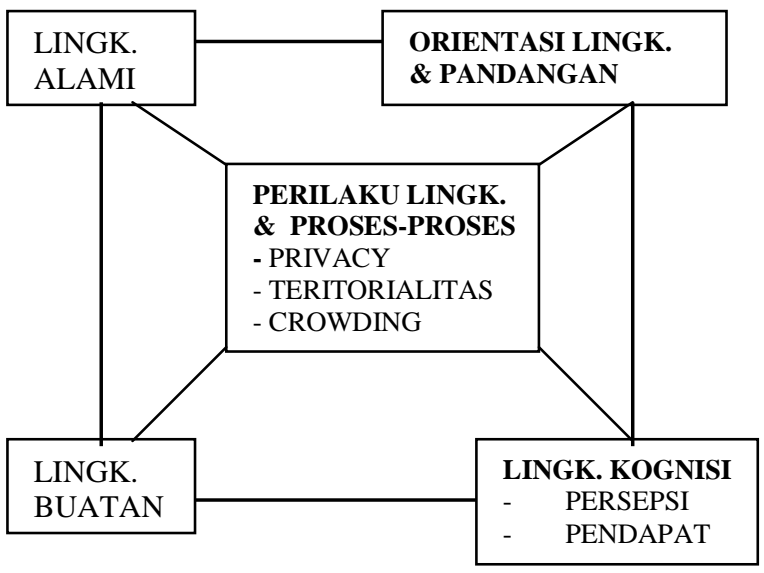

Gambar 1: Proses bubungan manusia dengan lingkungannya (Irwin Altman, 1980)

Ke lima unsur tersebut saling berkait satu dengan lainnya serta bertindak sebagai faktor penyebab atau dapat pula merupakan sebagai akibat. Seperti dalam gambar di atas bahwa privacy, teritoriality, personal space dan crowding dipengaruhi oleh persepsi, lingkungan buatan, iklim dan norma-norma yang berlaku. Begitu juga sebaliknya, kalau lingkungan buatan berubah maka akan diikuti perubahan yang lainnya. Perubahan pada bagian sistem akan berpengaruh pada seluruh suprasistem. Berdasarkan teori-teori di atas, bahwa hubungan manusia dengan lingkungannya merupakan jalinan erat yang tidak dapat dipisahkan karena satu dengan yang lainnya saling mempengaruhinya.

\section{Ruang Lingkup Perilaku dengan Lingkungan}

Ruang Lingkup perilaku manusia dengan lingkungannya terdapat tiga komponen pokok, yaitu kelompok pemakai (user group), rona (setting), dan konsep tingkah laku manusia dengan lingkungannya (Environmental-Behavior Concept). (Altman, 1975)

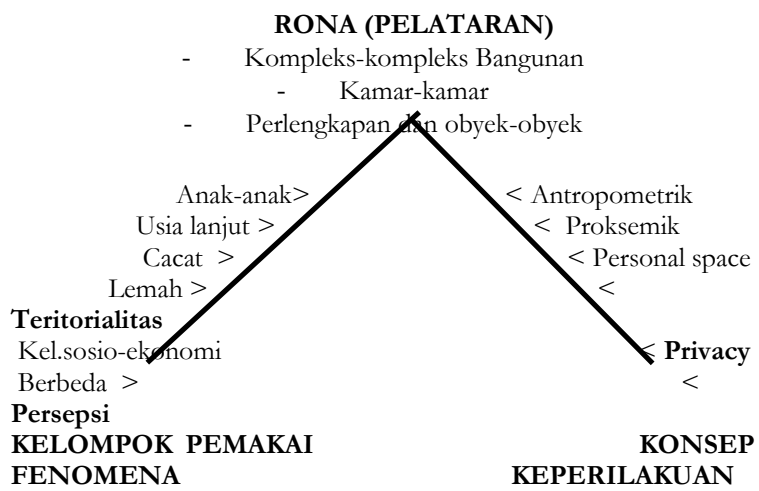

Gambar 2: Proses hubungan manusia dengan lingkungannya (Irwin Altman, 1975)

\section{Keleluasaan Pribadi (Privacy)}

Keleluasaaan pribadi adalah kemampuan sesorang mengendalikan dan mengatur kemungkinankemungkinan didekati, dihubungi dan dicari informasi tentang dirinya oleh pihak lain Westin (1970) membagi keleluasaan pribadi ke dalam beberapa jenis yaitu : 
- Solutide : keinginan untuk menyendiri, bebas dari pengamatan pihak luar

- Intimacy: keinginan intim bersama orang lain tertentu yang bebas dari pihak lain

- Anonymity : tak mau dikenali oleh pihak lain, sekalipun ia berada dikeramaian

- Reserve : seseorang yang memakai batas psikologis untuk menanggulangi gangguan pihak lain yang tak diingin Seseorang perlu keleluasaan pribadi untuk memperoleh rasa otonom, membebaskan diri dari emosi, membantu mengevauasi diri serta untuk membuat batas dan melindungi diri pada waktu komunikasi.

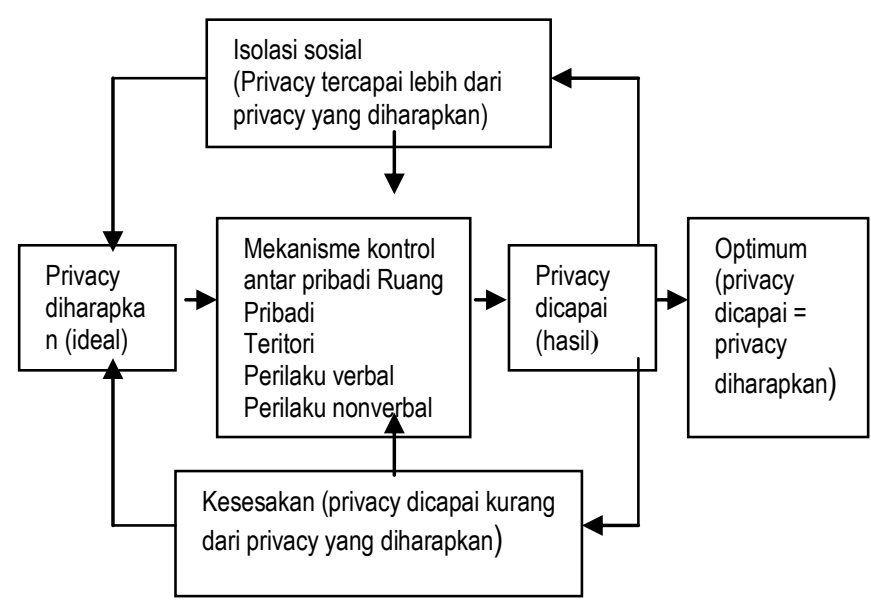

Gambar 3 : Skema hubungan antara privacy, ruang pribadi, teritorialitas, dan kesesakan (Altman, 1975)

Model yang menghubungkan privacy, personal space, teritoriality dan crowding. Dalam mempertahankan personal space dan memperlihatkan perilaku teritorial merupakan dua mekanisme yang digunakan orang untuk mencapai tingkat keleluasaan pribadi yang diinginkan dalam keadaan bersesakan guna menghindarkan stress yang tidak semestinya. Model yang menghubungkan antara keleluasaan pribadi, ruang pribadi, teritorialitas dan kesesakan dapat dilihat pada gambar 3 .

Berdasarkan teori-teori di atas, bahwa seseorang membutuhkan privacy untuk mengatur diri dalam berinteraksi sosial guna mendapatkan kenyamanan. Adapun keleluasaan pribadi dapat diuraikan lagi ke dalam : gangguan suara, keterlihatan oleh orang lain yang tidak diinginkan, ketercampuran dengan kegiatan lain).

\section{Teritorialitas (Teritoriality)}

Teritorialitas menunjukkan pada sekelompok rona perilaku bahwa seorang ingin mempribadi, menyatakan diri, memiliki, dan bertahan. Teritori merupakan daerah yang tetap atau tidak dapat dipindahkan. Ada lima ciri teritori, yaitu : Memuat daerah ruang (spatial), dimiliki atau dikendalikan oleh individu atau kelompok, memenuhi kebutuhan atau dorongan tertentu, ditandai secara konkrit maupun simbolis, dan dipertahankan atau pemilik merasa terganggu bila ada orang lain melanggarnya.

Erich Fromm (1974) berpendapat bahwa manusia dikuasai oleh naluri untuk mempertahankan teritorinya. Teritori penting bagi manusia untuk menyatakan wilayah kekuasaan yang menjadi hak miliknya, agar dapat melakukan berbagai kegiatan 
dengan leluasa. Teritori ini menyangkut masalah kepemilikan, penggunaan, pengawasan dan pemeliharaan suatu tempat/obyek.

Teritori dapat dibagi menjadi 3 bagian sebagai berikut :

1) Teritori Utama, misalnya; ruang tidur, ruang kerja, pekarangan suatu rumah, dan lain lain

2) Teritori Sekunder, misalnya; ruang tamu, ruang keluarga, pintu masuk pekarangan, jalan, taman suatu kota.

3) Teritori Umum, misalnya; jalan di muka rumah, taman.

Teritori ini penting untuk pemenuhan keleluasaan pribadi untuk memenuhi kebutuhan akan identitas, kepemilikan, aktualisasi diri, rasa aman, memelihara hubungan atau interaksi dengan pihak lain.

\section{Kesesakan (Crowding)}

Kesesakan adalah kondisi adanya stimulus yang berlebihan atau kondisi terdapatnya peningkatan kerumitan sosial atau adanya sindroma dari muatan yang berlebihan atau adanya suatu interaksi yang tak diinginkan dan tak terkendali. Kesesakan merupakan akibat dari kegagalan untuk mencapai tingkat privacy yang diinginkan. Kepadatan adalah hubungan antara ukuran ruang dan jumlah manusia. Mengurangi luasan ruang tempat manusia tinggal akan mengakibatkan kekacauan pada perilaku, berlanjut pada tekanan terhadap jiwa. Adapun kesesakan dapat diurakan lagi dalam : Keteraturan gerak, jumlah manusia, hubungan antar manusia, jumlah kegiatan yang dilakukan, tata tertib)

\section{METODOLOGI}

\section{Rancangan Penelitian}

Penelitian ini dilakukan dengan cara memaparkan secara sistematis, faktual, dan akurat mengenai faktafakta pada perilaku interaksi sosial penghuni rusunawa yang bersifat deskriptip. Bentuk rancangan penelitian ini adalah studi kasus melalui survai lapangan dengan pengamatan langsung, wawancara, dan kuisener. Untuk mengukur kepuasan penghuni yang lebih rasional dengan menjaring opini atau pendapat berupa persepsi melalui responden. Berupa tanggapan penghuni terhadap aspek perilaku kebersamaan di fasilitas umum, variabelnya meliputi elemen-elemen perilaku : privacy, territoriality, crowding)

\section{Pengambilan Populasi dan Sampel}

Pangambilan data melalui wawancara dan kuesioner. Pengambilan sampel adalah purposive sampling, untuk mencerminkan sifat populasi yaitu dipilih berdasarkan penghuni yang menempati rusunawa lebih dari 5 tahun. Setiap lantai sampel berjumlah 5 responden, jadi setiap blok ada 15 responden. Jumlah sampel keseluruhan sebanyak 30 responden. Wawancara dilakukan tak berstruktur (bebas), sebelum wawancara mencatat pokok-pokok yang akan dibicarakan. Angket dilakukan dengan kombinasi antara angket tertutup dan terbuka. Pengamatan perilaku (observasi) : pengamatan perilaku kehidupan sehari-hari di fasilitas umum dan jejak fisik berupa barang-barang yang ditinggalkan. Pengamatan diupayakan tanpa diketahui responden. 


\section{Metode Pengolahan Data dan Analisa Data}

Pengolahan Data Survai berupa kuisener dan wancara dengan cara mengklasifikasi data dan menstabulasi data menurut pengolahannya. Analisa data alat pengukuran yang dipakai adalah analisis statistik model skala Likert dan Osgood.

Model skala Likert : Untuk mengetahui sikap responden secara kuantitatip terhadap beberapa pernyataan yang menunjukkan persetujuan atau tidak setuju.Apabila pernyataan sangat setuju nilainya 6 dan sangat tidak setuju nilai terendah 1 . kemudian menjumlah nilai pada pertanyaan atau pernyataan.

Model skala Osgood : Jenis Kuisener ini digunakan untuk mengukur arah, kualitas, dan intensitas dari pemaknaan yang dipresepsikan penghuni. Cara ini untuk menganalisis persepsi dan sikap manusia secara kuantitatip. Responden diminta menyatakan pendapatnya terhadap kata sifat yang disusun dalam dua kutub saling berlawanan. Data diambil berdasarkan definisi dari unsur-unsur kepuasan (privacy, territoriality, crowding) yang dikelompokkan atas dasar kata sifat yang berkonotasi negatip berada sebelah kiri dengan nilai bobot 1 (sangat kurang memuaskan) dan kata sifat yang berkonotasi positip berada sebelah kanan dengan nilai bobot 5 (sangat memuaskan). Pengolahan data Pengamatan dengan cara melihat langsung, berupa hasil rekaman video atau foto-foto, kemudian membuat gambar pola gerak pemakai pada gambar denah dimana ruang (space) yang sering ditempati kegiatan bersama pada rona perilakunya (setting behavior).

\section{Metode Penafsiran Data}

Metode Penafsiran Skala Likert : Apabila hasil analisis data dari 10 pertayaan dari salah satu rona (setting) didapatkan nilai yang lebih besar mendukung atau lebih besar 40, maka hasil analisis data tersebut ditafsirkan bahwa interaksi sosial sangat baik di tempat tersebut. Sebaliknya apabila nilai kurang dari 40, maka ditafsirkan bahwa interaksi sosial sangat kurang.

Metode Penafsiran Skala Osgood : Apabila hasil analisis data dari 10 pertanyaan didapatkan nilai yang lebih besar mendukung atau lebih besar 30, maka hasil analisis data tersebut ditafsirkan bahwa penghuni merasa nyaman (memuaskan). Sebaliknya apabila nilai kurang dari 30, maka ditafsirkan bahwa penghuni merasakan kurang nyaman (kurang memuaskan).

Metode Penafsiran Pengamatan : apabila pada gambar denah terlihat pola orang melakukan kegiatan bersama (berkerumun) lebih dari 3 orang, maka ditafsirkan penghuni telah terjadi interaksi sosial, kemudian terlihat pola rona perilakunya (behavior setting).

\section{HASIL DAN PEMBAHASAN \\ Profil Penghuni \\ Data Umum Responden}

Tabel 1: Data umum profil responden

\begin{tabular}{|l|l|r|}
\hline No & Keterangan & \% dari sample \\
\hline 1. & Lama tinggal : -8 tahun & 26.67 \\
\hline & 8 - 10 tahun & 73.33 \\
\hline 2 & Jenis Kelamin : Laki-laki & 46.67 \\
\hline & Perempuan & 53.33 \\
\hline 3 & Umur sekarang : a. $20-30$ th & 16.67 \\
\hline & b. $30-40$ th & 30 \\
\hline & c. $40-50$ th & 16.67 \\
\hline & d. $50-60$ th & 33.33 \\
\hline & e. $>60$ th & 3.33 \\
\hline
\end{tabular}




\begin{tabular}{|c|c|c|}
\hline 4 & Agama Islam & 100 \\
\hline \multirow[t]{5}{*}{5} & Asal sebelum tinggal di rusunawa & \\
\hline & a. di sekitar rusunawa < $1 \mathrm{KM}$ & 56.67 \\
\hline & b. Dekat $1-3 \mathrm{KM}$ & 6.67 \\
\hline & c. $>3 \mathrm{Km}$ & 0 \\
\hline & d. Luar Kota Malang & 36.67 \\
\hline \multirow[t]{2}{*}{6} & Suku/Etnis : Jawa & 56.67 \\
\hline & Madura & 43.33 \\
\hline \multirow[t]{2}{*}{7} & Status Runah : Kontrak & 36.67 \\
\hline & Rumah sendiri/sewa & 63.33 \\
\hline \multirow[t]{5}{*}{8} & Jarak tempat Pekerjaan & \\
\hline & a. di sekitar rusunawa $<1 \mathrm{KM}$ & 83.33 \\
\hline & b. Dekat $1-3 \mathrm{KM}$ & 6.67 \\
\hline & c. $>3 \mathrm{Km}$ & 6.67 \\
\hline & d. Luar Kota Malang & 3.33 \\
\hline \multirow[t]{3}{*}{9} & Jenis Pekerjaan & \\
\hline & a. Wiraswasta & 73.33 \\
\hline & b. Swasta & 26.67 \\
\hline \multirow[t]{5}{*}{10} & Tingkat pendidikan & \\
\hline & a. SD TT (SD Tidak Tamat) & 6.67 \\
\hline & b. Lulus SD & 53.33 \\
\hline & c. Lulus SMP & 26.67 \\
\hline & d. Lulus SMA & 13.33 \\
\hline \multirow[t]{6}{*}{11} & Jumlah penghuni dalam 1 unit & \\
\hline & a. dua orang & 6.67 \\
\hline & b. Tiga orang & 20 \\
\hline & c. empat orang & 26.67 \\
\hline & d. lima orang & 30 \\
\hline & e. lebih dari lima orang & 16.67 \\
\hline
\end{tabular}

Sebagian besar responden yang terjaring sudah seimbang. Seperti responden antara laki-laki dan perempuan, prosentase laki-laki $46.67 \%$ dan perempuan $53.33 \%$. Asal Suku/Etnis dari suku Jawa $56.67 \%$ dan suku madura $43.33 \%$. Responden yang terjaring sudah memenuhi kriteria yaitu bertempat tinggal lebih dari 5 tahun, sedangkan responden antara $5-8$ tahun $=26.67 \%$ dan lama tinggal antara $>8-10$ tahun $=73.33 \%$, hal ini bisa mewakili penghuni secara keseluruhan dan diharapkan keakuratan data dapat dijamin.

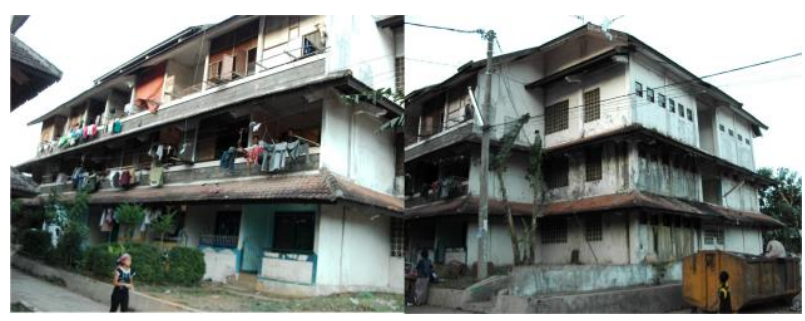

Gambar 4. Tampilan Gedung Rusunawa

\section{Kepuasan Penghuni Privacy (keleluasaan Pribadi)}

Tabel 2. Profil Privacy (kele;uasan Pribadi) terhadap pemakaian fasilitas Umum di Rusunawa Kuto Bedah (sumber : Pengelolaan Data dan Analisa peneliti, 08)

\begin{tabular}{|c|c|c|c|c|c|c|c|}
\hline \multirow{2}{*}{$\begin{array}{l}\mathbf{N} \\
\mathbf{O}\end{array}$} & \multirow{2}{*}{$\begin{array}{c}\text { SUB UNSUR } \\
\text { PRIVACY NEGATIP }\end{array}$} & \multicolumn{5}{|c|}{ NILAI } & \multirow{2}{*}{$\begin{array}{c}\text { SUB UNSUR } \\
\text { PRIVACY POSITIP }\end{array}$} \\
\hline & & 1 & 2 & 3 & 4 & 5 & \\
\hline 1 & $\begin{array}{l}\text { Anak-anak bermain di } \\
\text { Selasar bersuara gadau }\end{array}$ & & & & i & & $\begin{array}{l}\text { Anak-anak bermain di } \\
\text { Selasar tidak bersuara } \\
\text { gadau }\end{array}$ \\
\hline 2 & $\begin{array}{l}\text { Orang yang } \\
\begin{array}{l}\text { berbincang- } \\
\text { bincang } \\
\text { berisik }\end{array}\end{array}$ & & & | & $\begin{array}{l}1 \\
\vdots \\
\vdots\end{array}$ & & $\begin{array}{l}\text { Orang yang berbincang- } \\
\text { bincang di selasar } \\
\text { bersuara tidak berisik }\end{array}$ \\
\hline 3 & $\begin{array}{l}\text { Sering orang tidak di- } \\
\text { kenal lewat di selasar/ di } \\
\text { depan rumah. }\end{array}$ & & & I & & & $\begin{array}{l}\text { Jarang orang tidak di- } \\
\text { kenal lewat di selasar/ di } \\
\text { depan rumah. }\end{array}$ \\
\hline 4 & $\begin{array}{l}\text { Sering orang yang tidak } \\
\text { dikenal ikut memakai } \\
\text { MCK umum }\end{array}$ & & & & & & $\begin{array}{l}\text { Jarang orang yang tidak } \\
\text { dikenal ikut memakai } \\
\text { MCK umum }\end{array}$ \\
\hline 5 & $\begin{array}{lr}\text { Tempat Cuci } & \text { bersama } \\
\text { sering dipakai tempat } \\
\text { bergunjing }\end{array}$ & & & & & & $\begin{array}{l}\text { Tempat Cuci bersama } \\
\text { jarang dipakai tempat } \\
\text { bergunjing }\end{array}$ \\
\hline 6 & $\begin{array}{lll}\text { Sering ada tetangga yang } \\
\text { mampir di } & \text { dapur } \\
\text { bersama } & & \\
\end{array}$ & & & & & & $\begin{array}{l}\text { Jarang ada tetangga yang } \\
\text { mampir di tempat dapur } \\
\text { bersama }\end{array}$ \\
\hline 7 & $\begin{array}{l}\text { Dapur Bersama mudah } \\
\text { dilihat orang yang tidak } \\
\text { dikenal }\end{array}$ & & & & & & $\begin{array}{l}\text { Dapur Bersama sulit } \\
\text { dilihat orang yang tidak } \\
\text { dikenal }\end{array}$ \\
\hline 8 & $\begin{array}{l}\text { Rahasia Dapur } \text { Bersama } \\
\text { mudah dilihat } \\
\text { masaknya }\end{array}$ & & & & & & $\begin{array}{ll}\text { Rahasia Dapur } & \text { Bersama } \\
\text { sulit dilihat tetangga } \\
\text { masaknya }\end{array}$ \\
\hline 9 & $\begin{array}{lr}\begin{array}{l}\text { Dapur bersama } \\
\text { dipakai }\end{array} & \text { sering } \\
\text { bergunjing } & \text { tempat } \\
\end{array}$ & & & & & & $\begin{array}{lr}\begin{array}{l}\text { Dapur bersama } \\
\text { dipakai } \\
\text { bergunjing }\end{array} & \begin{array}{l}\text { jarang } \\
\text { tempat }\end{array} \\
\end{array}$ \\
\hline
\end{tabular}




\begin{tabular}{|l|l|l|l|l|l|l|l|}
\hline 1 & $\begin{array}{l}\text { Sering terjadi keributan } \\
\text { dalam pemakaian ruang } \\
\text { bersama }\end{array}$ & & & & $\begin{array}{l}\text { Jarang terjadi keributan } \\
\text { dalam pemakaian ruang } \\
\text { bersama }\end{array}$ \\
\hline
\end{tabular}

Keterangan :

1. Sangat kurang memuaskan

2. Kurang memuaskan

3. Cukup

Lantai I =

Lantai II $=\overline{-\cdots \cdot \cdot \cdot-}$

Lantai III $=\ldots--\cdot--$

\section{Memuaskan}

5. Sangat Memuaskan

Grafik di atas dapat disimpulkan, bahwa yang dirasakan privacy penghuni di rusunawa, cukup memuaskan, namun masih ada yang dianggap kurang memuaskan. Menurut hasil wawancara dari beberapa responden, bahwa permasalahan privacy dianggap tidak ada masalah, karena sudah beradaptasi dengan kondisi yang ada.

Semakin ke atas suara gadau tidak begitu mengganggu. Penghuni dalam berinteraksi sosial sesama penghuni sering terjadi di Selasar, penghuni merasa puas dengan penggunaan fasilitas umumnya.

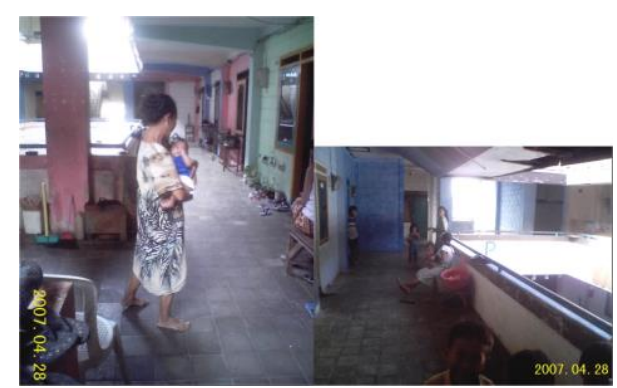

Gambar 5. Selasar tempat untuk bermain anak-anak dan ibu-ibu momong putranya.

\section{Teritoriality (teritorialitas)}

Tabel 3. Profil Teritoriality (teritorialitas) terhadap pemakaian fasilitas Umum di Rusunawa Kuto Bedah

(sumber : Pengelolaan Data dan Analisa peneliti, 2008)

\begin{tabular}{|c|c|c|c|c|c|c|c|}
\hline \multirow[b]{2}{*}{$\begin{array}{l}\mathbf{N} \\
\mathbf{O}\end{array}$} & \multirow{2}{*}{$\begin{array}{c}\text { SUB UNSUR } \\
\text { TERITORIALITAS } \\
\text { NEGATIP }\end{array}$} & \multicolumn{5}{|c|}{ NILAI } & \multirow{2}{*}{$\begin{array}{c}\text { SUB UNSUR } \\
\text { TERITORIALITAS } \\
\text { POSITIP }\end{array}$} \\
\hline & & 1 & 2 & 3 & 4 & 5 & \\
\hline 1 & $\begin{array}{l}\text { Selasar terasa sempit ke- } \\
\text { tika mengobrol bersama } \\
\text { tetangga }\end{array}$ & & & & & & $\begin{array}{l}\text { Selasar terasa luas ketika } \\
\text { anda mengobrol bersa- } \\
\text { ma tetangga }\end{array}$ \\
\hline 2 & $\begin{array}{l}\text { Tangga terasa sempit ke- } \\
\text { tika berjalan bersama } \\
\text { keluarga }\end{array}$ & & & & & & $\begin{array}{l}\text { Tangga terasa luas ke-tika } \\
\text { anda berjalan bersa-ma } \\
\text { dengan keluarga }\end{array}$ \\
\hline 3 & $\begin{array}{lrr}\text { Ruang } & \mathrm{KM} / \mathrm{WC} & \text { Umum } \\
\text { terasa sempit } & \text { ketika } \\
\text { mencuci bersama } & \\
\end{array}$ & & & & & & $\begin{array}{l}\text { Ruang KM/WC Umum } \\
\text { terasa luas ketika mencuci } \\
\text { bersama }\end{array}$ \\
\hline 4 & $\begin{array}{l}\text { Dapur } \text { bersama terasa } \\
\text { sempit ketika memasak } \\
\text { bersama }\end{array}$ & & & & & & $\begin{array}{l}\text { Dapur bersama terasa } \\
\text { luas ketika memasak } \\
\text { bersama }\end{array}$ \\
\hline 5 & $\begin{array}{l}\text { Merasa kurang aman da- } \\
\text { lam menyimpan barang } \\
\text { pribadi di ruang bersama }\end{array}$ & & & & & & $\begin{array}{lr}\text { Merasa aman dalam } \\
\text { menyimpan } \\
\text { pribadi di ruang bersama }\end{array}$ \\
\hline 6 & $\begin{array}{l}\text { Merasa sulit menghen- } \\
\text { tikan tetangga yang se- } \\
\text { dang bersenda gurau di } \\
\text { depan rumah }\end{array}$ & & & & & & $\begin{array}{l}\text { Sangat mudah meng- } \\
\text { hentikan tetangga yang } \\
\text { sedang bersenda gurau di } \\
\text { depan rumah }\end{array}$ \\
\hline 7 & $\begin{array}{l}\text { Sangat sulit mengusir } \\
\text { secara halus kepada te- } \\
\text { tangga yang ngobrol di } \\
\text { depan rumah }\end{array}$ & & & & & & $\begin{array}{l}\text { Sangat mudah mengusir } \\
\text { secara halus kepada } \\
\text { tetangga yang ngobrol di } \\
\text { depan rumah }\end{array}$ \\
\hline 8 & $\begin{array}{l}\text { Sering sekali tetangga } \\
\text { meletakkan barang pri- } \\
\text { badi seenaknya di fasiitas } \\
\text { umum }\end{array}$ & & & & & & $\begin{array}{l}\text { Jarang sekali tetangga } \\
\text { meletakkan barang pri- } \\
\text { badi seenaknya di Fasili } \\
\text { tas umum }\end{array}$ \\
\hline 9 & $\begin{array}{l}\text { Sering barang tertukar } \\
\text { atau hilang di tempat } \\
\text { jemuran }\end{array}$ & & & & & & $\begin{array}{l}\text { Jarang barang tertukar } \\
\text { atau hilang di tempat } \\
\text { jemuran }\end{array}$ \\
\hline $\begin{array}{l}1 \\
0\end{array}$ & $\begin{array}{l}\text { Sering tetangga me- } \\
\text { minjam barang priba- } \\
\text { di tanpa seijin }\end{array}$ & & & I & & & $\begin{array}{l}\text { Jarang tetangga me- } \\
\text { minjam barang priba- } \\
\text { di tanpa seijin }\end{array}$ \\
\hline
\end{tabular}

\section{Keterangan :}

1. Sangat kurang memuaskan 4. Memuaskan

2. Kurang memuaskan 5. Sangat Memuaskan

3. Cukup

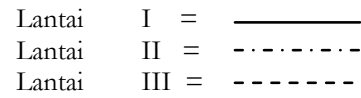


Grafik di atas dapat disimpulkan, bahwa yang dirasakan teritorialitas oleh penghuni rusunawa, cukup memuaskan.. Menurut hasil pengamatan bahwa Selasar dimanfaatkan penggunaannya secara optimal, seperti Selasar tidak hanya sebagai jalan penghubung, tetapi juga sebagai dapur, sebagai ruang tamu, sebagai tempat ternak ayam (kombong), dll.

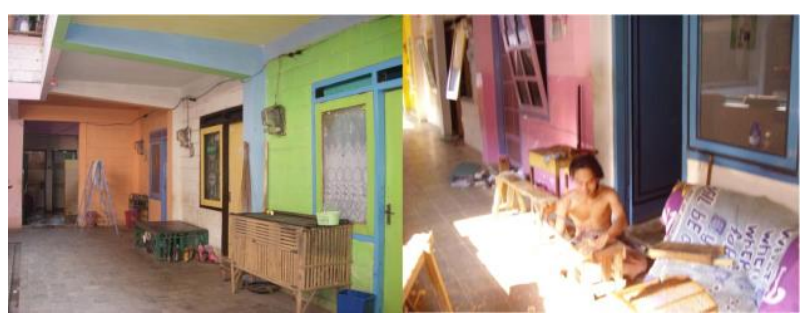

Gambar 6. Selasar merupakan ruang publik alih fungsikan sebagai sebagai tempat ternak (kombong) dan sebagai tempat produksi para pengrajin

\section{Crowding (Kesesakan)}

Tabel 4. Profil Crowding (kesesakan) terhadap pemakaian fasilitas Umum di Rusunawa Kuto Bedah (sumber : Pengelolaan Data dan Analisa peneliti, 08)

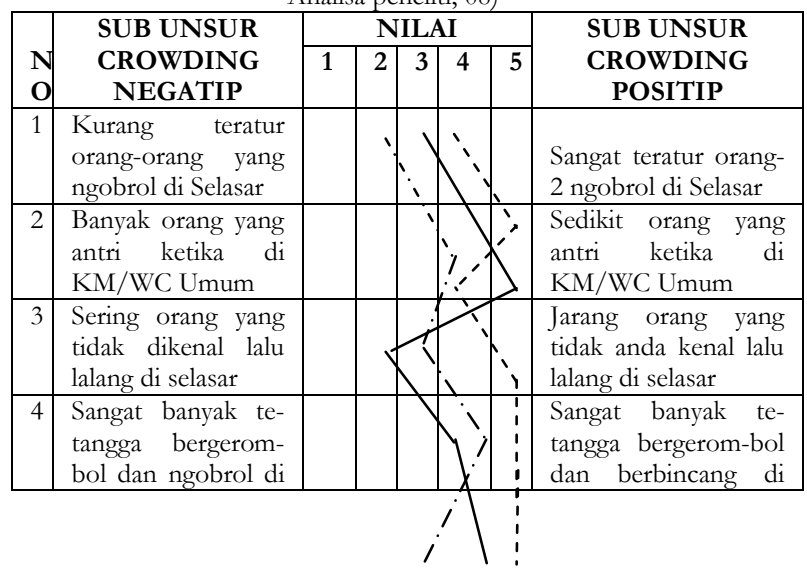

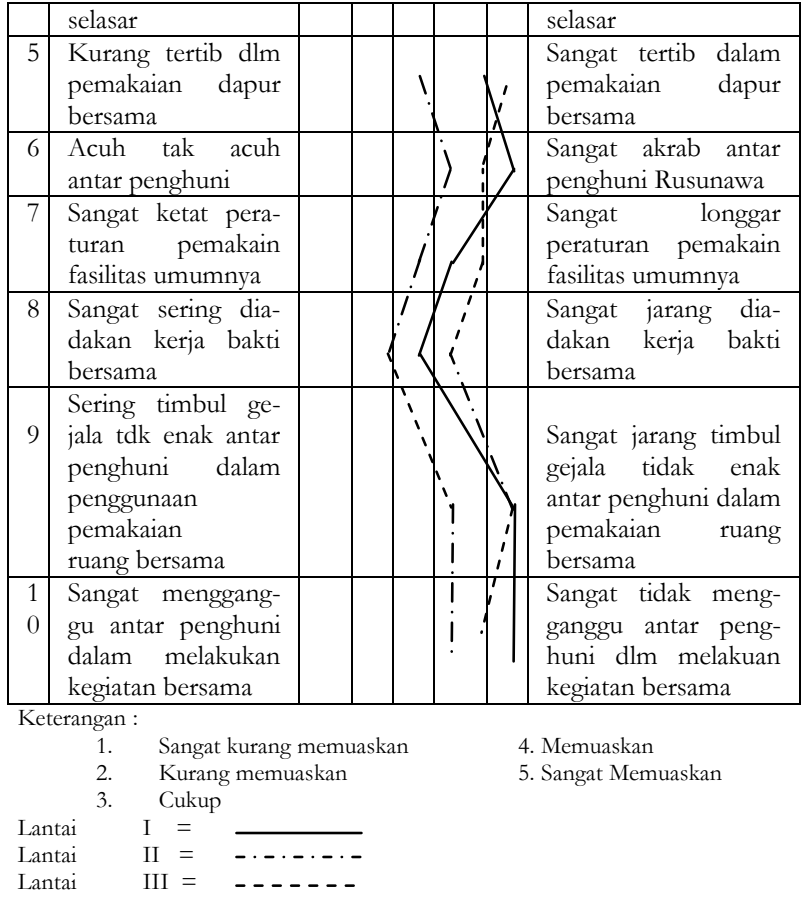

Pernyataan kesesakan berhubungan erat dengan kepadatan (jumlah orang), ketidak teraturan susunan ruang, dll. Grafik di atas dapat disimpulkan, bahwa penghuni tidak mengalami kesesakan (crowding). Menurut hasil survai bahwa responden sebagian besar menginginkan ruang yang fleksible dapat mengakomodasi berbagai aktivitas. 


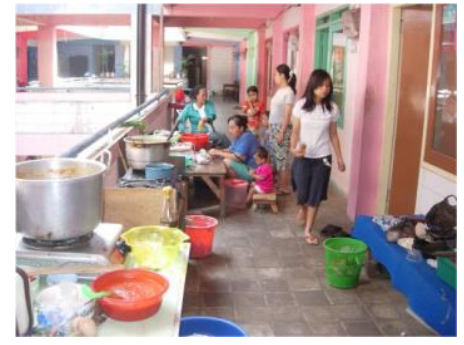

Gambar 7. Selasar untuk Dapur

Berdasarkan pengamatan, bahwa kesesakan di selasar disebabkan adanya pengalihan fungsi menjadi dapur, ruang tamu, tempat produksi, dll..

\section{Skala sikap Responden di Selasar}

Tabel 5: Skala sikap Responden di Selasar

\begin{tabular}{|c|c|c|c|}
\hline no & Lantai & & Bobot \\
\hline 1 & I & & 46.2 \\
\hline 2 & II & & 50.8 \\
\hline 3 & III & & 46.8 \\
\hline \multicolumn{4}{|c|}{ Keterangan: } \\
\hline $\begin{array}{l}\text { Sanga } \\
\text { Setuju } \\
\text { Ragu- }\end{array}$ & $\begin{array}{l}=60 \\
=50 \\
=40\end{array}$ & $\begin{array}{l}\text { ragu2 tidak setuju } \\
\text { tidak setuju }=20 \\
\text { sangat tidak setuju }\end{array}$ & $=30$ \\
\hline
\end{tabular}

Berdasarkan tabel di atas, bahwa responden rata-rata memberikan tanggapan positip. Berarti kebersamaan di Selasar terjadi dengan baik. Terutama terletak di lantai II, karena penghuni memanfaatkan selasar sebagai ruang tamu atau ruang duduk-duduk. Selasar di lantai I, dipakai untuk tempat parkir sepeda motor, sehingga jarang ada anak-anak bermain. Sedangkan lantai III ada sebagian ruang digunakan sebagai dapur dan produksi.

\section{Skala sikap Responden di MCK umum}

\begin{tabular}{l} 
Tabel 6: Skala sikap Responden di MCK Umum \\
\begin{tabular}{|c|c|c|}
\hline no & Lantai & Bobot \\
\hline 1 & I & 40 \\
\hline 2 & II & 43.6 \\
\hline 3 & III & 42 \\
\hline Keterangan: & $=60 \quad$ ragu2 tidak setuju $\quad=30$ \\
Sangat setuju & $=50 \quad \begin{array}{l}\text { tidak setuju= 20 } \\
\text { Setuju }\end{array}$ \\
Ragu-ragu setuju & $=40 \quad$ sangat tidak setuju $\quad=10$
\end{tabular} \\
\hline
\end{tabular}

Berdasarkan tabel di atas, bahwa responden rata-rata memberikan tanggapan positip. Berarti kebersamaan di MCK umum terjadi dengan baik. Terutama terletak di lantai II, karena penghuni memanfaatkan MCK umum dengan baik.

\section{Skala sikap Responden di Dapur Umum}

Tabel 4 : Skala sikap Responden di Dapur Umum

\begin{tabular}{l|c|c|}
\hline no & Lantai & Bobot \\
\hline 1 & I & 30 \\
\hline 2 & II & 42.8 \\
\hline 3 & III & 35.6 \\
\hline Keterangan : & & ragu2 tidak setuju $=30$ \\
Sangat setuju & $=60 \quad$ tidak setuju = 20 \\
Setuju & $=50 \quad$ sangat tidak setuju $=10$ \\
Ragu-ragu setuju & $=40 \quad$
\end{tabular}

Berdasarkan tabel di atas, bahwa responden rata-rata memberikan tanggapan positip, tapi masih ragu-ragu. Berarti kebersamaan di Dapur umum masih kurang dimanfaatkan. Berdasarkan pengamatan sebagian dapur memang tidak digunakan, justru membuat dapur di selasar dan di belakang rumah tinggal. 


\section{Pengamatan}

Pada umumnya anak-anak bermain di selasar lenih menyukai bermain di sekitar orang berjualan, ada fasilitas tempat duduk dan punya keleluasaan untuk bergerak. Biasanya ibu-ibu sambil momong putranya di selasar sambil ngobrol dengan tetangganya. Biasanya orang-orang berkumpul dengan berdiri, duduk di lantai dan duduk di kursi. Selasar yang letaknya di depan rumah dengan adanya Void bisa saling melihat antar penghuni tiap-tiap lantai, terkesan memperkuat interaksi sosial.

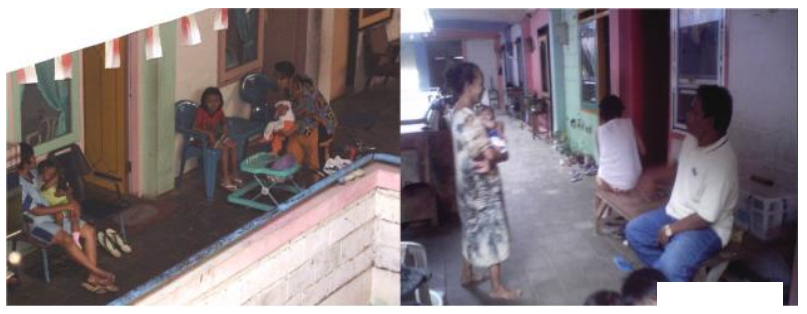

Gambar 8. Selasar tempat yang paling disukai berinteraksi sosial

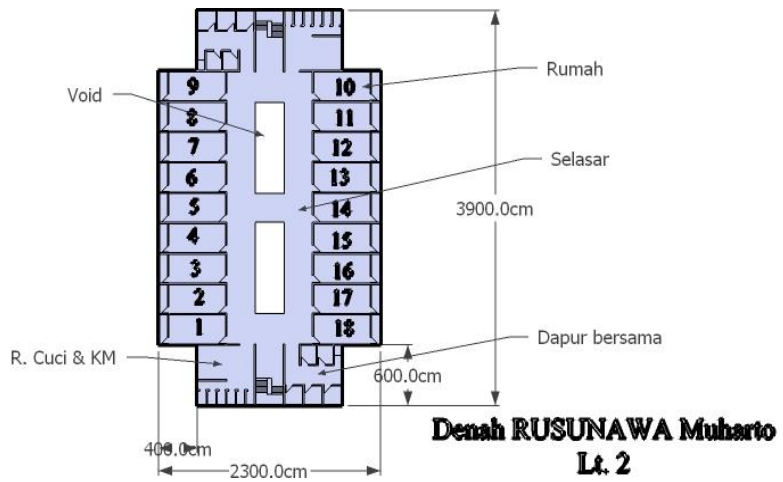

Gambar 9. Selasar tempat yang paling disukai berinteraksi sosial

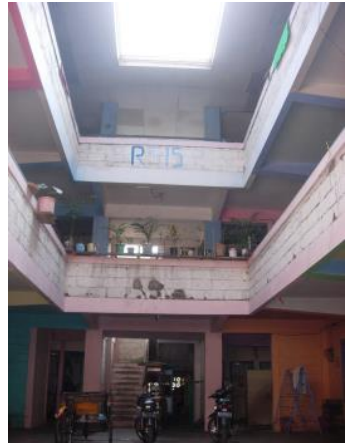

Gambar 10. Void di Rusunawa Kuto Bedah Kota Malang

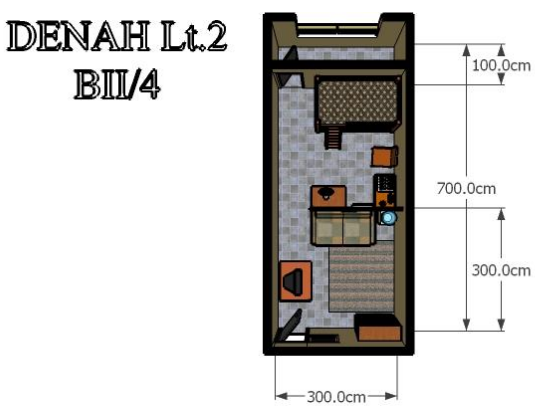

Gambar 10. Denah unit rumah tinggal

\section{KESIMPULAN}

\section{Kepuasan Penghuni (Privacy, Teritoriality, Crowding)}

Sebagian besar responden merasakan kepuasan terhadap kegiatan bersama di fasilitas umum, baik di selasar, MCK umum, dan dapur umum. Namun tempat yang paling disukai adalah di Selasar. Sangat beralasan karena letaknya tepat di depan pintu, ruang geraknya cukup luas, menghadap ke dalam, adanya void dan pencahayaan alami dari atas, antar lantai bisa 
terlihat, merupakan disain yang sesuai dengan yang dikehendaki oleh penghuni dalam berinteraksi sosial.

MCK umum kebersamaan hanya dilakukan pada saat mencuci bersama dan pada saat antri ke kamar mandi. Adapun dapur bersama kurang diminati untuk berinteraksi sosial, justru ada yang membuat dapur di selasar letaknya dekat dengan tempat tinggal.

\section{Rona Perilaku (Behavior Setting)}

Rona perilaku penghuni kebersamaan terletak di fasilitas umum, seperti di selasar, di tangga, MCK umum dan dapur umum. Rona yang dikehendaki apabila ada fasilitas yang mendukung kebersamaan, antara lain ruang yang cukup luas untuk menampung aktivitas, ada kursi, dan ada pencahayaan yang cukup.

\section{REFERENSI}

Altman, Irwin at. al (1975): The Environment and Social Behavior: Privacy, Personal Space, Territory, and Crowding, Brooks/Cole Publishing Co, Monterey.

Altman, Irwin (1980): Culture and Environment, Brooks/Cole Publishing Co, Monterey.

Bell, Paul A (1978) : Environmental Psychology, WB. Saunders co, Philadelphia.

Bechtel, Robert B (1987) : Methods in Environmental and Behavioral Research, Van Nostrand Reinhold Company, New York.

Brolin, B.C. (1976) : The Failure of Modern Architecture, Studio Vista, London.

Budiharjo, Eko (1984) : Sejumlah Masalah Permukiman Kota, Alumni, Bandung.

Canter, David (1981) : Psychology for Architects, Applied science Publishers, London.
Freedman, JL (1981) : Social Psychology, Prentice Hall Inc, New York.

Hall, Edward T. (1966) : Hidden Dimension, Double Day and co, New York.

Heimsath, Clovis, AIA. , (1977) : Behavioral Architecture, Mc.Graw-Hill, New York.

Hesselgren, sven (1975): Man's perception of Manmade environment, Dowden, Hutchinson \& ross, Stroudsburg, Pennysylvania.

Jencks, Charles (1977) : The Language of Post Modern Architecture, Academy, London

Lang, Jon (1987) : Creating Architectural Theory, Nostrand Reinhold Co.

Levy, Claude \& Leboyer (1982) : Psychology and Environment, Sage Punlications, Beverly Hill.

Lewin, Kurt (1951) : Field Theory in social science, Harper \& Brothers Publisher, New York.

Menteri Negera Perumahan Rakyat (2006) : Gerakan Nasional Pembangunan Sejuta Rumah (GNPSR), Jakarta.

Michelson, William (1973) : Behavioral Research Methods in Environmental Design, Hutchinon \& Ross, Stroudsbrug.

More, Gary T (1985) : Environmental Design Research Directions-Process and prospect, Praeger publisher, New York.

Nasution, S (1987) : Metode Research, Jemars, Bandung

Osgood, CE, et. al. (1967) : The Measurement of meaning, University of Illinois Pres, Urbana.

Sommer, Robert, 1983 : Social Design, Prentice-Hall, London

Subagijo, Edi (1998) : Pola Perilaku Kebersamaan di Rumah Susun, Surabaya Hasil Peremajaan Kawasan Kumuh di Perkotaan, Mintakat, Jurusan Teknik Arsitektur Unmer Malang, Malang.

Subagijo, Edi (2004) : Rancangan Ruang Bersama di Rumab Susun Sewa Terbadap Pola Perilaku 
Penghuninya dalam Berinteraksi Sosial. Lemlit Unmer Malang, Malang.

Zeisel, John (1981) : Inquiry by Design; Tools for Environment-Behavior Research, books/cole Publishing Co, Monterey. 